CASSOWARY volume 4 (2) Juni 2021: 221-233

ISSN : 2614-8900

E-ISSN : 2622-6545

Program Pascasarjana Universitas Papua, https://pasca.unipa.ac.id/

\title{
Analisis Kualitas Air Lindi Dan Permukaan Diareal TPA Sowi Gunung Dan Sekitarnya Di Kabupaten Manokwari, Papua Barat
}

\author{
Novaldi Laudi Angrianto ${ }^{1}$, Jacob Manusawai ${ }^{1}$, Anton S. Sinery ${ }^{1}$ \\ ${ }^{1}$ Program Studi S2 Ilmu Lingkungan, Program Pascasarjana Universitas Papua, Jalan \\ Gunung Salju Amban Manokwari, 98314, Papua Barat, Indonesia \\ *Email: anton_sineri@yahoo.com
}

Disubmit: 11 Februari 2021, direvisi: 20 Juni 2021, diterima: 27 Juni 2021

Doi: https://doi.org/10.30862/casssowary.cs.v4.i2.79

\begin{abstract}
The aim of the research was to determine the quality of leachate water in the processing unit (IPAL) of TPA Sowi Gunung and the quality of surface water around the TPA in relation to the operation of the IPAL TPA.The method used in this research was descriptive method with cross sectional survey technique by collecting leachate samples from the IPAL unit and surface water samples from two springs around the landfill area.It was accompanied by in-situ measurements of $\mathrm{pH}$ parameters and continued with 6 parameter quality analysis others (TSS, TDS, BOD, COD, N-total, TOC) at the Laboratory of the Research Center for Environmental Assessment, University of Papua. The result of the research was known that the parameters of $\mathrm{pH}$, TSS, BOD, COD, N-total, and TOC in the TPA IPAL unit were categorized as under quality standards (PerMenLHK No.59 of 2016).In particular, the TDS parameter does not have a tolerance limit corresponding to this quality standard so it becomes a separate consideration in its management considering that water with a high amount of dissolved solids> $1000 \mathrm{mg} \mathrm{/} \mathrm{L}$ that has an unpleasant taste, so it is not suitable for consumption.Likewise, the quality of surface water at 2 (two) observation points of springs through parameters of $\mathrm{pH}$, TSS, TDS, BOD, COD, N-total, and TOC were categorized as under class I water quality standards according to PP No. 82 of 2001 concerning water quality management and water pollution control.
\end{abstract}

Keywords: leachate, surface water, pH, TSS, TDS, BOD, COD, N-total, TOC, TPA, Manokwari

\section{PENDAHULUAN}

Indonesia merupakan negara yang memiliki komposisi sampah basah lebih besar dari sampah kering dan sampah basah menghasilkan kandungan air yang sangat tinggi dibandingkan sampah kering, sehingga menghasilkan air lindi yang besar pula (REF). Menurut Damanhuri (2010) dalam Srikandi (2014), airlindi (leachate) adalah cairan yang merembes melalui tumpukan sampah dengan membawa materi terlarut atau tersuspensi terutama hasil proses dekomposisi materi sampah.

Zat pencemar dalam air lindi seperti kesadahan, mangan, nitrit, besi, BOD, COD dan logam berat akan mengalir meninggalkan timbunan sampah yang menyebabkan pencemaran pada air permukaan maupun air tanah (Srikandi, 
2014). Salah satu kelemahan dari sistem pengolohan sampah yaitu tidak adanya pengolahan air lindi sehingga dapat mencemari kualitas air yang ada disekitar TPA. Menurut Herlambang dan Indriatmoko (2005) dalam Gunawan dkk (2016), air tanah adalah air yang bergerak di dalam tanah yang terdapat didalam ruang antar butir-butir tanah yang meresap ke dalam tanah dan bergabung membentuk lapisan tanah. Lapisan tanah dapat dibedakan menjadi lapisan permeable dan lapisan impermeable. Lapisan permeable adalah lapisan tanah yang dapat ditembus oleh air, yang terbentuk dari hasil endapan pasir atau kerikil. Sedangkan lapisan impermeable adalah lapisan yang kedap air sehingga air tidak akan mampu melewati lapisan ini. Menurut Alfiandy (2013) dalam Saleh dan Purnomo (2014), air lindi akan merembes melalui tanah secara perlahan. Apabila terdapat aliran air tanah di bawah lokasi TPA, maka air lindi akan mencemari aliran tersebut dengan kandungan zat yang cukup berbahaya bagi lingkungan.

Air lindi yang dihasilkan seharusnya dilakukan pengolahan terlebih dahulu sebelum dibuang. Jika air lindi tersebut tidak ditangani dengan benar dan langsung dibuang ke tanah maka akan mencemari kualitas air yang berada disekitar lingkungan TPA. Menurut Said, dkk (2015), pengolahan lindi sebagian besar TPA di Indonesia masih menggunakan teknologi sistem kolam, yaitu menggunakan kolam penampung, kolam anaerobik, kolam aerobik, kolam stabilisasi, dan dilanjutkan dengan menggunakan wetland. Kelemahan teknologi tersebut adalah waktu tinggal yang relatif lama yakni antara $30-50$ hari sehingga bangunan kolam membutuhkan lahan yang cukup luas. Selain itu hasil olahan lindi masih di atas baku mutu yang diijinkan untuk dibuang ke badan lingkungan (REF).
Menurut Soemirat (2009) dalam Srikandi (2014), bahaya atau resiko kesehatan yang berhubungan dengan pencemaran air secara umum dapat diklasifikasikan menjadi dua yakni bahaya langsung dan tidak langsung. Bahaya langsung terhadap kesehatan manusia/masyarakat dapat terjadi akibat mengkonsumsi air yang tercemar atau air kualitas yang buruk, baik secara langsung diminum atau melalui makanan, dan akibat penggunaan air yang tercemar untuk berbagai kegiatan sehari-hari.

Menurut Munawar (2011), berbagai penelitian telah dilakukan untuk mengetahui karakteristik air lindi. Pada umumnya hasil yang diperoleh menunjukkan bahwa parameter air lindi yaitu mengandung BOD, COD jauh lebih besar dari pada air buangan. Hal ini disebabkan karena dari timbunan sampah yang masih baru, biodegradasi umumnya berlangsung cepat yang ditandai dengan kenaikan produksi asam dan penurunan $\mathrm{pH}$ air lindi yang mengakibatkan kemampuan pelarutan bahan-bahan pada sampah oleh air menjadi tinggi (REF). Kemungkinan tercemarnya air sangat besar terutama jika terjadi infiltrasi dari air limpasan dan limbah dari hasil kegiatan manusia.

Beberapa hasil penelitian telah menunjukan adanya dampak yang cukup besar terkait letak TPA terhadap kualitas air sekitarnya. Winni (2012) menyebutkan bahwa kandungan nitrat telah melebihi batas baku mutu dalam air sumur gali masyarakat di sekitar tempat pembuangan (TPA) sampah di Desa Namo Bintang Kecamatan Pacur Batu Kabupaten Deli Serdang. Kurniawan (2006) menyebutkan bahwa parameter fisik, kimia dan mikrobiologi air sumur di wilayah sekitar TPA Galuga telah melampaui ambang batas maksimum yang diperbolehkan di TPA Gabuga Cibungbulong Bogor. Hal 
tersebut terlihat dari 11 parameter (bau, rasa, pH, DO, BOD5, COD, ammonia, nitrit, seng, bakteri coliform dan fecal coli (E. coli) yang telah melampaui ambang batas maksimum sesuai baku mutu kelas I. Demikian halnya Arbain, dkk (2008) yang menyebutkan bahwa parameter TDS, BOD, COD, DO, PO4, NO3, NO2, NH3, Besi, $\mathrm{H}_{2} \mathrm{~S}$, Fenol, dan $\mathrm{Cl}$ telah melebihi baku mutu terkait pengaruh air lindi tempat pembuangan akhir sampah TPA Suwung di kota Denpasar.

TPA Sowi Gunung merupakan salah unit pengelolaan sampah yang dikelola dengan sistem sanitary landfill guna menunjang target Manokwari sebagai kota bersih. Berdasarkan hasil wawancara (dengan pengelola unit) dan survei awal diketahui bahwa TPA ini telah berumur $>10$ tahun dan dilengkapi dengan beberapa sarana penunjang termasuk IPAL yang dilengkapi 4 unit bak/kolam pengolahan lindi. Menurut Mamboai dkk (2020), spesifikasi TPA Sowi Gunung dibangun dengan menggunakan sistem semi sanitary landfill, dengan luas lahan $12.000 \mathrm{~m}^{2} \quad(120 \mathrm{~m} \quad \mathrm{x} \quad 100 \mathrm{~m})$ dan kedalaman bak mencapai 5 meter. Total volume sampah yang dapat ditampung di TPA Sowi Gunung mencapai $60.000 \mathrm{~m}^{3}$. Beberapa infrastruktur pendukung yang terdapatdi TPA Sowi Gunung antara lain bak penampung lindi, workshop, rumah pengomposan, dan gudang. Sementara dalam menunjang operasional penanganan TPA Sowi Gunung terdapat tiga unit kendaraan bull-dozer yang kondisi dua diantaranya rusak. Di sekitar TPA ini terdapat 2 mata air yang dimanfaatkan oleh masyarakat sekitar sebagai sumber air bersih untuk kebutuhan rumah tangga. Namun demikian informasi terkait kualitas air pada kedua mata air ini dalam hubungannya dengan operasional TPA belum diketahui secara ilmiah.

\section{METODE PENELITIAN}

Penelitian ini berlangsung selama tiga bulan dan dimulai pada bulan September sampai November Oktober 2020 dan dilaksanakan pada areal Tempat Pembuangan Akhir (TPA) sampah Sowi Gunung Kabupaten Manokwari. Metode yang digunakan dalam penelitian ini adalah metode deskripsif dengan teknik survey potong silang (cross-sectional) melalui pengumpulan sampel air lindi pada unit IPAL dan sampel air permukaan pada dua mata air di sekitar areal TPA disertai pengukuran secara in-situ terhadap parameter $\mathrm{pH}$ dan dilanjutkan analisis kualitas 6 parameter lainnya (TSS, TDS, BOD, COD, N-total, TOC) pada laboratorium Pusat Penelitian Lingkungan Hidup (PPLH) Universitas Papua. Data hasil analisis selanjutnya dibandingkan dengan baku mutu kualitas air lindi sesuai PerMenLHK No. 59 tahun 2016 tentang baku mutu lindi bagi usaha dan/atau kegiatan tempat pemrosesan akhir sampah baku dan baku mutu kualitas air (kriteria mutu air berdasarkan kelas I) sesuai PP No. 82 tahun 2001 tentang pengelolaan kualitas air dan pengendalian pencemaran air.

\section{HASIL DAN PEMBAHASAN Kualitas Air Lindi}

Berdasarkan hasil analisis laboratorium terhadap contoh air yang diambil dari lokasi unit pengolahan diketahui bahwa masih dalam kondisi normal sesuai baku mutu yang berlaku (Tabel 1).

Tabel 1. Hasil Uji Kualitas Air Lindi

\begin{tabular}{|c|c|}
\hline & Air Lindi \\
\hline arameter Satuan & $\begin{array}{c}\text { IPAL } \\
\text { Maku } \\
\text { Mutu* }\end{array}$ \\
\hline
\end{tabular}




\begin{tabular}{lccc}
\hline $\mathrm{pH}$ & - & 8.07 & $6-9$ \\
$\mathrm{TSS}$ & $\mathrm{mg} / \mathrm{L}$ & 77 & 100 \\
$\mathrm{TDS}$ & $\mathrm{mg} / \mathrm{L}$ & 2733 & - \\
BOD & $\mathrm{mg} / \mathrm{L}$ & 4.3 & 150 \\
$\mathrm{COD}$ & $\mathrm{mg} / \mathrm{L}$ & 16.5 & 300 \\
N-total & $\mathrm{mg} / \mathrm{L}$ & 0.701 & 60 \\
TOC & $\mathrm{mg} / \mathrm{L}$ & 17.4 & - \\
\hline
\end{tabular}

*PerMenLHK no. 59 thn 2016

\section{Parameter pH}

Nilai pH menyatakan intensitas keasaman atau alkalinitas dari suatu cairan encer dan mewakili konsentrasi hidrogen ionnya. Menurut Chapman (2000), nilai $\mathrm{pH}$ merupakan parameter penting dalam analisis kualitas air karena pengaruhnya terhadap prosesproses biologis dan kimia di dalamnya. Suatu lingkungan perairan dapat dikatakan baik jika memenuhi syarat untuk menjamin kehidupan dan mempunyai $\mathrm{pH}$ netral, yaitu berkisar 6,5-7,5 (Purwanti, 2005). Dalam beberapa kasus $\mathrm{pH}$ air yang jauh dari netral diketahui dapat memberikan dampak negatif bagi makhluk hidup, misalnya penurunan kekerasan gigi akibat konsumsi minuman yang memiliki $\mathrm{pH}$ lebih kecil dari 7 (Prasetyo, 2004).

Kadar $\mathrm{pH}$ air lindi TPA Sowi Gunung tergolong basa $(8,07)$ dan berada pada batas toleransi baku mutu air lindi sesuai PerMenLHK No. 59/2016. Kadar pH ini sesuai dengan Arbain dkk (2008) yang melaporkan bahwa $\mathrm{pH}$ air lindi TPA Suwung Bali sebesar 8,57. Salah satu faktor yang diduga mempengaruhi nilai $\mathrm{pH}$ air lindi adalah umur sampah. Menurut Priambodho (2005), bahwa pada proses pertambahan umur tumpukan sampah akan terjadi fase fermentasi metana sebagai hasil dekomposisi biologis anaerobik yang hampir sempurna dengan nilai $\mathrm{pH}$ berfluktuasi 7,5 - 9 .

\section{Parameter Total Padatan Tersus- pensi (TSS)}

Total Suspended Solid (TSS) didefinisikan sebagai jumlah bobot bahan tersuspensi dalam suatu volume tertentu yang dinyatakan dalam $\mathrm{mg} / \mathrm{liter}$. Sumber suspensi ini dapat berasal dari kotoran hewan, manusia, lumpur, dan limbah industri (Sastrawijaya, 2000) serta dapat pula berasal dari sisa-sisa tumbuhan. TSS merupakan salah satu bagian dari zat padat dalam air selain zat padat terlarut dan koloidal (REF). Analisis zat padat penting dilakukan bagi penentuan komponen-komponen air secara lengkap juga untuk perencanaan serta pengawasan proses pengolahan dalam bidang air minum maupun air buangan (Alaerts dan Santika, 1987).

Air lindi TPA Sowi Gunung memiliki kadar TSS sebesar $77 \mathrm{mg} / \mathrm{L}$ dan masih berada di bawah baku mutu sesuai PerMenLHK No. 59 tahun 2016. Kadar tersebut menggambarkan bahwa potensi material TSS yang cukup besar dalam sampah di TPA ini,dan masih terlihat melalui proses sirkulasi menuju unit IPALyangdapat terlihat dari endapan suspensi pada kolam IPAL yang berwarna hitam pekat. Jumlah hujan yang cukup tinggi mengakibatkan kadar TSS dalam air menurun karena terjadi pengenceran kadar zat tersuspensi dan sebaliknya. Jika kadar TSS melebihi $100 \mathrm{mg} / \mathrm{L}$, maka TSS tersebut menunjukan jumlah kepekatan padatan tersuspensi yang terdiri dari zat organik dan anorganik berupa ion-ion antara lain Sodium, Kalsium, Magnesium, Bikarbonat, Sulfat, Klorida, Besi, Kalium, Karbonat, Nitrat, Strontium, Boron dan Silika yang tinggi dan melayang-layang dalam air lindi sampah (Effendi, 2003). Secara fisik keberadaan TSS umumnya dapat dikenali sebagai penyebab kekeruhan pada air. Limbah cair yang mempunyai 
kandungan zat tersuspensi tinggi tidak boleh dibuang langsung ke badan air karena disamping dapat menyebabkan pendangkalan juga dapat menghalangi sinar matahari masuk kedalam dasar air sehingga proses fotosintesa mikroorganisme (fitoplanton) tidak dapat berlangsung (Erni, 2013). Proses fotosintesis ini merupakan salah satu penyedia oksigen terlarut dalam air, sehingga bila proses ini terhalang, maka proses dekomposisi hanya dapat terjadi secara anaerobik. Aktifitas mikroba yang hidup di bagian badan air yang anaerob selain menghasilkan sel-sel mikroba baru juga menghasilkan senyawa-senyawa $\mathrm{CO}_{2}, \mathrm{NH}_{3}, \mathrm{H}_{2} \mathrm{~S}$, dan $\mathrm{CH}_{4}$ serta senyawa lainnya seperti amin, $\mathrm{PH}_{3}$ dan komponen fosfor (REF). Asam sulfide $\left(\mathrm{H}_{2} \mathrm{~S}\right)$, amin dan komponen fosfor adalah senyawa yang mengeluarkan bau menyengat yang tidak sedap, misalnya $\mathrm{H}_{2} \mathrm{~S}$ berbau busuk dan amin berbau anyir (REF). Selain itu disinyalir bahwa $\mathrm{NH}_{3}$ dan $\mathrm{H}_{2} \mathrm{~S}$ hasil dekomposisi anaerob pada tingkat konsentrasi tertentu dapat beracun dan oleh karenanya membahayakan organisme lain, termasuk ikan (Erni, 2013).

\section{Parameter Total Padatan Terlarut (TDS)}

Zat padat adalah material tersuspensi atau terlarut dalam air yang dapat mempengaruhi kualitas air (Djuhariningrum, 2005). Air lindi TPA Sowi Gunung memiliki kadar TDS yang tergolong cukup tinggi yaitu 2.733 $\mathrm{mg} / \mathrm{L}$. Hal ini dikarenakan air lindi sangat banyak mengandung material organik dan anorganik serta padatan dan mikro organisme yang apabila dimasukkan kembali ke dalam sampah, akan terakumulasi di dalam sampah (REF). Namun demikian masih dalam batas toleransi sesuai baku mutu (PerMenLHK No. 59 tahun 2016).Air dengan jumlah zat padat terlarut tinggi $>1000 \mathrm{mg} / \mathrm{L}$ mempunyai rasa yang tidak enak, sehingga tidak layak dikonsumsi sebagai air minum.Apabila TDS bertambah, maka kesadahan akan bertambah pula, danakan mempengaruhi daya hantar listrik (REF). Semakin banyak ion bermuatan listrik, maka akan mempengaruhi dan mempermudah daya hantar listrik. Selain itu, TDS menyebabkan kekeruhan (turbidity) serta mempengaruhi salinitas karena senyawa terlarut menyebabkan air menjadi asin (Djuhariningrum, 2005). Resirkulasi air lindi ke dalam tumpukan sampah dapat menyebabkan akumulasi ion klorida dan amonia karena tidak digunakan kembali selama proses degradasi sampah (REF). Karena ion klorida dan amonia ini merupakan salah satu komponen penyusun TDS, menyebabkan konsentrasi TDS pada lysimeter 2 yang menerapkan system resirkulasi air lindi menjadi lebih tinggi dibandingkan dengan lysimeter 1(Erni, 2013).

\section{Parameter Biochemical Oksigen Demand (BOD)}

BOD merupakan jumlah oksigen yang dibutuhkan oleh mikroorganisme untuk mengoksidasi zat-zat organik menjadi bentuk anorganik yang stabil (Chapman, 2000). BOD adalah suatu analisa empiris yang mencoba mendekati secara global proses-proses mikrobiologis yang benar-benar terjadi di dalam air. Angka BOD adalah jumlah oksigen yang dibutuhkan oleh bakteri untuk menguraikan (mengoksidasi) hampir semua zat organik yang terlarut dan sebagian zat-zat organik yang tersuspensi dalam air.

Hasil analisis menunjukkan bahwa nilai BOD pada air lindi TPA cukup rendah yaitu 4,3 $\mathrm{mg} / \mathrm{L}$ dan masih berada dibawah baku mutu sesuai PerMenLHK No. 59 tahun 2016. Hal ini dikarenakan 
jumlah bahan organik yang tergolong rendah sehingga tidak membutuhkan oksigen yang banyak. Jika kadar BOD melebihi $150 \mathrm{mg} / \mathrm{L}$, maka konsentrasi BOD ini menggambarkan mengandung material oraganik pula. Adanya konsentrasi yang tinggi akan membutuhkan banyak oksigen untuk melakukan proses dekomposisi secara biologis (biodegradable) oleh mikroorganisme aerob (REF). Penguraian zat organik adalah peristiwa alamiah, jika suatu badan air tercemar oleh zat organik maka bakteri akan dapat menghabiskan oksigen terlarut dalam air selama proses biodegradable berlangsung, sehingga dapat mengakibatkan kematian pada biota air dan keadaan pada badan air dapat menjadi anaerobik yang ditandai dengan timbulnya bau busuk (Erni, 2013).

\section{Parameter Chemical Oxigen Demand (COD)}

Kebutuhan oksigen kimiawi (COD) adalah ukuran indikasi dari jumlah oksigen yang dapat dikonsumsi oleh reaksi dalam larutan yang diukur, umumnya dinyatakan dalam massa oksigen yang dikonsumsi miligram per liter $(\mathrm{mg} / \mathrm{l})$. COD adalah jumlah total oksigen yang diperlukan agar bahan buangan yang ada di dalam air dapat teroksidasi melalui reaksi kimia (Munawar, 2011). Sebuah tes COD dapat digunakan untuk menghitung kandungan organik dalam larutan. Penggunaan paling umum dari COD adalah dalam mengukur jumlah polutan teroksidasi yang ditemukan dalam air permukaan (misalnya danau dan sungai) atau air limbah (REF).

Hasil analisis menunjukkan bahwa nilai COD pada air lindi TPA cukup rendah yaitu $16,5 \mathrm{mg} / \mathrm{L}$ dan masih berada dibawah baku mutu. Jika kadar COD melebihi $300 \mathrm{mg} / \mathrm{L}$, maka konsumsi oksigen tinggi ditunjukkan dengan semakin kecilnya sisa oksigen terlarut, sehingga kandungan bahanbahan buangan yang membutuhkan oksigen juga tinggi. Dengan demikiantingginya COD merupakan indikator adanya pencemaran yang paling penting untuk menentukan kekuatan atau daya cemar air limbah (Erni, 2013).

\section{Parameter N-total}

Nitrogen adalah nutrien penting dalam sistem biologis mahluk hidup. Proporsi nitrogen berupa nitrogen organik dan nitrogen amonia dalam air limbah, tergantung degradasi bahan organik yang berlangsung (REF). Senyawa nitrogen organik dapat ditransformasi menjadi nitrogen amonium dan dioksidasi menjadi nitrogen nitrit dan nitrat dalam sistem biologis mahluk hidup (Saeni, 1989). Amonia $\left(\mathrm{NH}_{3}\right)$, nitrit $\left(\mathrm{NO}_{2}{ }^{-}\right)$dan nitrat $\left(\mathrm{NO}^{-}\right)$merupakan senyawa-senyawa yang mengandung unsur nitrogen $(\mathrm{N})$. Unsur $\mathrm{N}$ sebagai salah satu unsur makro yang penting dibutuhkan untuk petumbuhan suatu organisme. Di dalam perairan, kebanyakan senyawa-senyawa nitrogen dijumpai dalam bentuk organik dan anorganik (Mahida, 1997).

Hasil analisis menunjukkan bahwa nilai COD pada air lindi TPA cukup rendah yaitu $0,71 \mathrm{mg} / \mathrm{L}$ dan masih berada dibawah baku mutu. Jika kadar $\mathrm{N}$-total melebihi $60 \mathrm{mg} / \mathrm{L}$, maka dapat menyebabkan methaemoglobinemia, yaitu kondisi dimana hemoglobin $(\mathrm{Hb})$ didalam darah sehingga darah menjadi kekurangan oksigen dan dikenal dengan penyakit "babie blues" pada bayi (REF). Hal ini dapat mengakibatkan pengaruh yang fatal serta dapat mengakibatkan kematian khususnya pada bayi(Srikandi, 2014).Selain itu, senyawa nitrogen berikatan dengan perak (argentum) sebagai senyawa debu, yang dapat menimbulkan iritasi pada kulit dan 
menghitamkan kulit (argyria) karena ketika kedua senyawa ini saling berikatan, maka argentum akan menjadi sangat korosif. Kondisi tersebut mengakibatkan argyria dapat terjadi karena senyawa ini diakumulasikan di dalam selaput lendir dan kulit (Srikandi, 2014).

\section{Parameter Total Organik Karbon (TOC)}

Total OrganicKarbon (TOC) adalah jumlah carbon yang menempel/ terkandung didalam senyawa organik dan digunakan sebagai salah satu indikator kualitas air (air bersih maupun air limbah). Dari hasil uji kualitas air pada sampel air lindi pada pemeriksaan parameter TOC yaitu 17,4 mg/L. Namun, dalam baku mutu (PerMenLHK No. 59 tahun 2016 tentang baku mutu lindi bagi usaha dan/atau kegiatan tempat pemrosesan akhir sampah), tidak tercantum batas maksimalparameter TOC

Pada PerMenLHK No. 59 tahun 2016 dalam persyaratan parameter kualitas air tanah yang dipantau pada sumur pantau atau sumur uji tercantum parameter kimia organik. Semua bahan organik mengandung karbon (C) yang berkombinasi dengan satu atau lebih elemen lainnya (Effendi, 2003). Bahan organik dikelompokkan menjadi tiga kelompok utama yaitu alifatik, aromatik, dan heterosiklik, dan semua kelompok tersebut memiliki beberapa contoh senyawa yang cukup banyak (Sawyer dan McCarty, 1978).

Kenyataan menunjukkan bahwa untuk penentuan masing-masing bahan organik tersebut cukup sulit dan sangat komplek. Meskipun TOC merupakan bagian dari bahan organik, tetapi pada PerMenLHK No. 59 tahun 2016 parameter bahan organik hanya mencakup batas-batas maksimum bahan kimia organik saja. Selanjutnya karbon diperairan juga terdapat dalam bentuk karbon organik yang berasal dari tumbuhan atau biota akuatik, baik yang hidup atau yang mati dan menjadi detritus (Effendi, 2003). Dengan pengujian TOC, semua senyawa karbon organik dalam perairan akan dapat diketahui dalam bentuk jumlah total (tidak spesifik), sehingga TOC dapat menjadi alternatif untuk mengetahui parameter kimia organik pada PerMenLHK No. 59 tahun 2016.

Hasil wawancara dengan Kepala Bidang Persampahan Dinas Lingkungan Hidup Kabupaten Manokwari selaku perwakilan pengelola TPA Tempat Pembuangan Akhir (TPA) sampah diketahui bahwa pada lapisan landfill yang seharusnya berfungsi sebagai tempat mengalirnya air lindi mengalami kebocoran akibat terjadinya kebakaran pada beberapa waktu sebelumnya sehingga diduga terjadi inflitrasi air lindi pada TPA.

\section{Kualitas Air Permukaan}

Hasil uji menunjukan bahwa 7 parameter kimia air (Tabel 2) yang dianalisis secara keseluruhan masih berada pada batas tolerensi sesuai baku mutu yang berlaku sebagaimana pada air lindi.

Tabel 1. Hasil Uji Kualitas Air Permukaan

\begin{tabular}{lcccc}
\hline \multirow{2}{*}{ Parameter } & \multirow{2}{*}{ Satuan } & \multicolumn{2}{c}{ Air Permukaan } & \multirow{2}{*}{ Baku Mutu* } \\
\cline { 3 - 4 } & & Site I & Site 2 & $6-9$ \\
$\mathrm{pH}$ & - & 7.22 & 6.92 & 50 \\
$\mathrm{TSS}$ & $\mathrm{mg} / \mathrm{L}$ & 4 & 3 & 1000 \\
$\mathrm{TDS}$ & $\mathrm{mg} / \mathrm{L}$ & 241 & 382 & \\
\hline
\end{tabular}




\begin{tabular}{lcccc}
\hline BOD & $\mathrm{mg} / \mathrm{L}$ & 1.6 & 1.4 & 2 \\
COD & $\mathrm{mg} / \mathrm{L}$ & 7.4 & 8.2 & 10 \\
N-total & $\mathrm{mg} / \mathrm{L}$ & 0.514 & 0.414 & 10.56 \\
TOC & $\mathrm{mg} / \mathrm{L}$ & 4.3 & 7.6 & - \\
\hline
\end{tabular}

Baku Mutu Kelas I (PP no. 82 Thn 2001)

\section{Parameter pH}

Derajat keasaman merupakan kekuatan antara asam dan basa dalam air dan suatu kadar konsentrasi ion hidrogen dalam larutan (Sutamihardja, 1978). Nilai pH menggambarkan kekuatan bahan pelarut dari air, karena itu penunjukkannya mungkin dari reaksi kimia pada batu-batuan dan tanahtanah. Pertumbuhan organisme perairan dapat berlangsung dengan baik pada kisaran $\mathrm{pH}$ 6,5 - 8,5. Namun menurut Effendi (2003) besarnya $\mathrm{pH}$ dapat digunakan sebagai petunjuk dalam memprediksi kualitas air. Jika nilai $\mathrm{pH}$ $=7$, air digolongkan netral, untuk $\mathrm{pH}<$ 7 air digolongkan asam dan untuk $\mathrm{pH}>$ 7 digolongkan basa.

Hasil pengujian menunjukan bahwa $\mathrm{pH}$ kedua mata air tersebut tergolong layak untuk di konsumsi sebagai air baku air minum sesuai Peraturan Pemerintah Nomor 82 Tahun 2001. Demikian halnya dengan Permenkes Nomor 492 Tahun 2010 tentang persyaratan kualitas air minum dimana pH memiliki ambang batas berkisan antara 6,5-8,5. Kondisi ini diduga dipengaruhi oleh kualitas lingkungan khususnya batuan yang diketahui merupakan batuan batu gamping (limestone), selain kondisi vegetasi dan faktor lingkungan lainnya.

\section{Parameter Total Padatan Tersus- pensi (TSS)}

Penyebab nilai zat tersuspensi yang utama adalah kikisan tanah atau erosi yang terbawa ke badan air (Effendi, 2003). Menurut Priyono (1994), bahan partikel yang tidak terlarut seperti pasir, lumpur, tanah, dan bahan kimia anorganik menjadi bentuk bahan tersuspensi di dalam air, sehingga bahan tersebut menjadi penyebab polusi tertinggi di dalam air.

Hasil analisis menunjukan bahwa nilai TSS pada mata air kedua lokasi pengamatan masih berada pada toleransi baku mutu dan dipengaruhi kondisi lingkungan seperti curah hujan, jenis tanah, topografi, kelerengan, dan tutupan vegetasi. Diketahui bahwa kedua titik pengambilan sampel ini merupakan daerah lereng yang berada pada cekungan sehingga memiliki vegetasi yang cukup rapat pada bagian atasnya yang menjadi faktor penentu besarnya limpasan permukaan dan potensi penyerapan air tanah.

\section{Parameter Total Padatan Terlarut (TDS)}

Zat padat terlarut merupakan padatan yang terdiri dari senyawa-senyawa organik dan anorganik yang larut di dalam air, termasuk mineral dan garam (Fardiaz, 1992).Hasil pengukuran nilai TDS pada kedua mata air masih berada pada toleransi baku mutu dan dipengaruhi oleh kondisi vegetasi yang masih cukup rapat, juga oleh kondisi lingkungan lainnya termasuk jarak mata air yang relatif dekat dengan TPA. Hal ini didukung oleh Djuhariningrum (2005) yang menyatakan bahwa penyebab utama keberadaan TDS di perairan adalah sisa-sisa bahan organik dan molekul sisa-sisa bahan buangan seperti molekul sabun, deterjen dan surfaktan yang larut dalam air. Kualitas air pada kedua titik pengamatan ini berdasarkan parameter TDS tergolong pada kategori layak untuk dikonsumsi sebagai air baku air minum bagi masyarakat sekitar. 


\section{Parameter Biochemical Oksigen Demand (BOD)}

Kebutuhan Oksigen Biologik (BOD) merupakan ukuran banyaknya oksigen yang diperlukan oleh jasad pengurai untuk merombak bahan organik yang ada dalam perairan dalam volume air tertentu (REF). Berdasarkan hasil pengukuran nilai BOD pada kedua mata air (titik pengamatan) tergolong pada kategori layak untuk di konsumsi sesuai PP No. 82 Tahun 2001 dan juga Permenkes Nomor 492 Tahun 2010 tentang persyaratan kualitas air minum dimana parameter BOD tidak memiliki ambang maksimal.

\section{Parameter Chemical Oxigen Demand (COD)}

Nilai COD menggambarkan total jumlah oksigen yang dibutuhkan untuk mengoksidasi bahan organik secara kimia, baik yang dapat didegradasi secara biologis maupun yang sukar didegradasi secara biologis menjadi karbondioksida dan air (Effendi, 2003). Hasil pengukuran COD pada kedua mata air menunjukkan nilai COD masih berada pada toleransi baku mutu dan layak untuk di konsumsi sesuai PP No. 82 Tahun 2001, dan juga Permenkes No. 492 Tahun 2010. Hasil uji kedua mata air tersebut menunjukkan kadar COD hampir mencapai ambang batas maksimal baku mutu, hal ini dikarenakan kadar COD menggambarkan bahwa tingginya jumlah total bahan organik pada kedua air permukaan, sebagaimana Effendi (2003) menyatakan bahwa semakin tinggi nilai COD semakin tinggi pula pencemaran oleh zat organik.

\section{Parameter N-total}

$\mathrm{N}$-total atau nitrogen total merupakan kalkulasi dari Amonia (NH3), nitrit $\left(\mathrm{NO}^{-}\right)$dan nitrat $\left(\mathrm{NO}^{-}\right)$yang menggambarkan senyawa-senyawa yang mengandung unsur nitrogen $(\mathrm{N})$. Berdasarkan hasil pengukuran nilai $\mathrm{N}$ total pada kedua mata air tersebut tergolong pada kategori layak untuk di konsumsi sesuai PP No. 82 Tahun 2001, dan juga Permenkes Nomor 492 Tahun 2010.

\section{Parameter Total Organik Karbon (TOC)}

Total Organik Karbon didefinisikan sebagai jumlah karbon yang terikat dialam senyawa organik yang terkadung didalam air (REF). Menurut Jenie (1993) Nilai TOC sangat berkolerasi dengan hasil analisi BOD dan COD bila limbah relatif seragam. TOC menggunakan pendekatan karbon akan tetapi tidak menunjukkan laju degradasi senyawa karbon. Senyawa - senyawa yang dianalisis dalam uji TOC seperti selulosa, hanya memecah secara lambat dalam lingkungan alamiah. Nilai TOC akan berubah apabila limbah diberi penanganan dengan berbagai metode. Hasil pengukuran menunjukkan bahwa nilai TOC tertinggi pada titik pengamatan 2 (dua) 7,6 $\mathrm{mg} / \mathrm{L}$ dan terendah pada titik pengamatan 1 yaitu 4,3 mg/L. Parameter TOC tidak memiliki batas maksimal yang tercantum pada baku mutu air pada PP No. 82 tahun 2001, demikian halnya dengan Permenkes Nomor 492 Tahun 2010. Secara umum hasil pengukuran menunjukan bahwa nilai TOC kedua mata air tersebut tergolong pada kategori layak untuk dikonsumsi karena parameter TOC memiliki korelasi terhadap parameter BOD dan COD, dimana hasil uji BOD dan COD menunjukan bahwa parameter tersebut memenuhi baku mutu.

Unsur-unsur pencemar air lindi sampah dari TPA Sowi Gunung diduga berinfiltrasi masuk ke dalam akifer air tanah disebabkan oleh masuknya air 
hujan ke dalam timbunan sampah. Hal ini akan menghanyutkan komponenkomponen sampah yang telah mengalami proses dekomposisi yang menghasilkan air lindi sampah (leachate) yang kemudian merembes keluar dari TPA sehingga menimbulkan pencemaran pada air sumur dan badan air lainnya di sekitar TPA. Pencemaran air lindi sampah akibat air hujan mencuci sampah yang sudah busuk serta segala kotoran yang terperangkap di dalamnya. Air lindi tersebut ada yang mengalir dipermukaan tanah yang dampaknya pada air permukaan, menimbulkan bau dan penyakit, sedangkan air lindi yang merembes ke dalam air tanah akan menimbulkan pencemaran air mata air di sekitarnya. Saway (2015) mengatakan bahwa rembesan air lindi yang terdapat dan telah tersebar pada daerah pinggiran lokasi TPA sampah telah mencapai jarak $\pm 50 \mathrm{~m}$ dari pinggiran TPA, dengan arah umum penyebaran lindi dari barat kearah selatan lokasi TPA. Air lindi yang menyebar umumnya mengikuti kemiringan morfologi setempat dengan kedalaman air lindi berkisar antara 1,71-8,0m dibawah permukaan tanah dan telah berakumulasi dengan satuan batu gamping yang terdapat pada areal TPA sampah.

Hasil analisis air lindi (TPA) dan air permukaan disekitar TPA dimana TPA memiliki ketinggian tertinggi \pm 145mdpl, sedangkan pada titik pengamatan 1 (satu) memiliki ketinggian yaitu $\pm 130 \mathrm{mdpl}$ dan pada titik pengamatan 2 (dua) memiliki ketinggian yaitu \pm 90 MDPL sehingga sangat berpotensi mencemari kualitas air permukaan karena TPA memiliki ketinggian lebih dibandingkan dengan pengambilan sampel air pada kedua air permukaan yang memiliki ketinggian dibawah lokasi TPA tersebut. Saway (2015) menyebutkan bahwa arah aliran sebaran air lindi dari timur ke barat. Hasil tersebut berbeda dengan penelitian ini karena hasil uji kualitas air menunjukkan bahwa air lindi TPA tidak memiliki pengaruh terhadap kualitas air permukaan disekitar TPA. Hal ini ditunjukkan oleh parameterparameter kualitas air permukaan yang masih berada pada batas toleransi baku mutu air kelas I (PP No. 82 tahun 2001) maupun Permenkes No.492 tahun 2016.

Kondisi tersebut dipengaruhi oleh kondisi curah hujan wilayah Manokwari yang cukup tinggi pada tahun 2020 (2.874,8 $\mathrm{mm} /$ tahun) sesuai data pada BPS Kabupaten Manokwari (2021). Curah hujan merupakan unsur iklim yang berpengaruh kualitas air secara langsung. Curah hujan adalah jumlah air yang jatuh di permukaan tanah datar selama periode tertentu yang diukur dengan satuan tinggi milimeter $(\mathrm{mm}) \mathrm{di}$ atas permukaan horizontal (REF). Curah hujan juga dapat diartikan sebagai ketinggian air hujan yang terkumpul dalam tempat yang datar, tidak menguap, tidak meresap dan tidak mengalir (REF). Air hujan yang jatuh di permukaan tanah dapat menyebabkan unsur kimia yang ada di permukaan tanah terlarut dalam air tersebut. Selanjutnya jenis batuan formasi geologi juga sangat berperan dalam mencegah atau mengurangi pencemaran air tanah dan air permukaan secara alami yang berasal dari air lindi. Formasi geologi TPA terdapat batu gamping terumbu, kalsirudit, kalkarenit dan batupasir, konglomerat, breksi neka bahan dan gampingan (REF). Tingkat peredaman sangat tergantung pada attenuation capacity (kemampuan peredaman) batuan (REF). Attenuation capacity mencakup permeabilitas, daya filtrasi, pertukaran ion, absorbsi, dan lain-lain. Demikian halnya dengan topografi dan kelerengan yang berhubungan dengan arah aliran air 
tanah terkait kedua sumber mata air serta keberadaan vegetasi. Diketahui bahwa areal sekitar TPA juga memiliki vegetasi yang baik sehingga mampu mendegradasi pencemaran akibat air lindi secara alami.Hal ini dikemukakan oleh penelitian Rachmawati (2014) yang mengatakan bahwa vegetasi riparian berperan penting dalam peningkatan kualitas air dimana vegetasi (hidromakrofita) mampu menurunkan konsentrasi beberapa parameter fisik-kimia air seperti bikarbonat, TSS, TDS, nitrat, ortofosfat, ammonium, TOM, suhu, konduktivitas serta meningkatkan kadar oksigen terlarut di bagian hilir saluran irigasi.

\section{KESIMPULAN}

Kualitas air lindi TPA melalui parameter $\mathrm{pH}$, TSS, BOD, COD, Ntotal, dan TOC dikategorikan aman karena masih berada dibawah standar baku mutu (PerMenLHK No. 59 tahun 2016 tentang baku mutu lindi bagi usaha dan/atau kegiatan tempat pemrosesan akhir sampah). Parameter TDS tidak memiliki batas toleransi sesuai baku mutu ini sehingga menjadi pertimbangan tersendiri dalam pengelolaannya mengingat air dengan jumlah zat padat terlarut tinggi $>1000$ $\mathrm{mg} / \mathrm{L}$ mempunyai rasa yang tidak enak, sehingga tidak layak dikonsumsi sebagai air minum.Kualitas air permukaan pada 2 (dua) titik pengamatan mata air melalui parameter $\mathrm{pH}$, TSS, TDS, BOD, COD, N-total, dan TOC dikategorikan aman untuk dikonsumsi sebagai air baku air minum untuk keberlangsungan hidup masyarakat disekitar TPA Sowi Gunung dikarenakan masih berada dibawah standar baku mutu air kelas I (PP No. 82 tahun 2001 tentang pengelolaan kualitas air dan pengendalian pencemaran air).

\section{DAFTAR PUSTAKA}

Alaert, G. dan S.S. Santika. 1987. MetodePenelitian Air. Usaha Nasional. Surabaya.

Arbain, N.K. Mardana., Sudana I.B. 2008. Pengaruh Air Lindi Tempat Pembuang Akhir Sampah Suwung Terhadap Kualitas Air Tanah Dangkal di Sekitarnya di Kelurahan Pendungan Kota Denpasar. Echotropic 3 (2) 211-226

Badan Pusat Statistik Kabupaten Manokwari Provinsi Papua Barat, Tahun 2020.

Chapman, D. 2000. Water Quality Assesment. E \& FN Spon. London.

Djuhariningrum T., 2005, Penentuan Total Zat Padat Terlarut dalam Memprediksi Kualitas Air Tanah dari berbagai Contoh Air, Pusat Pengembangan Geologi NuklirBatan, Jakarta.

Effendi, H. 2003. Telaah Kualitas Air Bagi Pengelolaan Sumber Daya dan Lingkungan Perairan. Kanisius, Yogyakarta.

Erni M. 2013. Pengaruh Lindi (Leachate) Sampah Terhadap Air Sumur Penduduk Sekitar Tempat Pembuangan Akhir (TPA) Air Dingin. Jurnal Kesehatan Masyarakat, Padang. Vol. 7 (No.2): 56-58.

Fardiaz, S. 1992. Polusi Udara dan Air. Karnisius. Yogyakarta.

Gunawan SA, Prasetyo Y, dan Amarrohman FJ. 2016. Studi Penentuan Kawasan Resapan Air Pada Wilayah DAS Banjir Kanal Timur. Program Studi Teknik Geodesi Fakultas Teknik, Universitas Diponegoro, Semarang. Vol5 (2) : 126.

Kurniawan, Bambang. (2006). Analisis kualitas air sumur sekitar wilayah tempat pembuangan akhir sampah (studi kasus di TPA Galuga 
Cibungbulang Bogor). Skripsi. FakultasTeknologi Pertanian IPB. Bogor.

Mahida, U.N. 1997. Pencemaran Air dan Pemanfaatan Limbah Industri. Rajawali. Jakarta.

Mamboai H, Sinery A.S, Wanggai C.B, Marhan M, Pamuji K.E, 2020. reviuw masterplan pengelolaan persampahan di Kabupaten Manokwari. Pusat Penelitian Lingkungan Hidup Universitas Papua

Munawar, A. 2011. Rembesan Air Lindi (Leachate) Dampak Pada Tanaman Pangan dan Kesehatan. Universitas Pembangunan Nasional Veteran Jatim, Surabaya.

Peraturan Menteri Lingkungan Hidup Dan Kehutanan Republik Indonesia Nomor

p.59/MENLHK/Setjen/KUM.1/7/201

6 Tentang Baku Mutu Lindi Bagi Usaha Dan/Atau Kegiatan Tempat Pemrosesan Akhir Sampah

Peraturan Menteri Kesehatan Republik Indonesia Nomor 492 Tahun 2010 tentang Persyaratan Kualitas Air Minum

Peraturan Pemerintah Republik Indonesia Nomor 82 Tahun 2001 tentang Penggelolaan Kualitas Air dan Pengendalian Pencemaran Air

Prasetyo EA. 2004. Keasaman minuman ringan menurunkan kekerasan permukaan gigi. Universitas Airlangga. Surabaya.

Priambodho K. 2005. Kualitas Air pada Tempat Pembuangan Akhir Sampah Galuga Kabupaten Bogor. IPB: Bogor.

Priyono, A. 1994. Parameter-parameter Kualitas Air. Laboratorium Analisis Lingkungan. Departemen Konservasi Sumberdaya Hutan. Fakultas Kehutanan. Bogor.

Purwanti AA, Sunarto, Setyaningsih R. 2005. Kualitas air tanah di sekitar
Aliran Sungai Pepe, Surakarta. BioSmart. Vol 7(No. 1):66- 71.

Rachmawati ET, dan Retnaningdyah C. 2014. Karakteristik Vegetasi Riparian dan Interaksinya dengan Kualitas Air Mata Air Sumber Awan Serta Salurannya di Kecamatan Singosari Malang. Jurnal Biotropika. Vol 2 (No.3).

Saeni, M.S. 1989. Kimia Lingkungan. Depdikbud, Ditjen Pendidikan Tinggi. PAU - Ilmu Hayat, IPB. Bogor.

Said NI, dan Hartaja DRK. 2015. Pengolahan Air Lindi Dengan Proses Biofilter Aaerob-Aerob dan Denitrifikasi. Pusat Teknologi Lingkungan, BPPT. JAI Vol 8 (No.1): 1-2.

Saleh C, dan Purnomo H. 2014. Analisis Efektifitas Instalasi Pengolahan Limbah Lindi Di TPA Supit Urang Kota Malang. Jurusan Teknik Sipil Universitas Muhammadiyah Malang. Vol 5 (No.1): 103-104.

Sastrawijaya AT. 2000. Pencemaran Lingkungan. Rineke Cipta. Jakarta.

Saway F.D, 2015. Identifikasi Arah Rembesan dan Letak Akumulasi Lindi Pada Tempat Pembuangan Akhir (TPA) Sampah Lokasi Sowi Kabupaten Manokwari. Pascasarjana Ilmu Lingkungan. Universitas Papua.

Sawyer, C.N. and P.L. McCarty. 1978. Chemystry for Environmental Enginerring Third edition. McGrawHill Book Company, Tokyo.

Srikandi, F. 2014. Analisis Kualitas Air Tanah Masyarakat di Sekitar Tempat Pembuangan Sampah Kelurahan Sumur Batu Bantar Gebang Bekasi. Univesitas Islam Negeri Syarif Hidayatullah Jakarta. Tugas Akhir. Program Studi Kesehatan Masyarakat Fakultas Kedokteran dan Ilmu Kesehatan Universitas Islam Negeri Syarif Hidayatullah, Jakarta. 
Sutamiharjda, 1978. Kualitas Pencemaran Lingkungan. Sekolah Pascaprasarjana Jurusan Pengelolaan Sumberdaya Alam dan Lingkungan. Bahan Kuliah: Instutit Pertanian Bogor. Bogor.

Winni, R. T., \& Surya, D. (2012). Analisis Kandungan $\mathrm{Pb}$ Pada Air Sumur Gali Masyarakat di Sekitar Tempat Penimbunan Limbah Padat Industri Timah Dari Daur Ulang Aki Bekas Desa Sei Rotan Kecamatan Sei Tuan Kabupaten Deli Serdang Tahun 2012. Program SarjanaFakultas Kesehatan Masyarakat Universitas Sumatera Utara Departemen Kesehatan Lingkungan. Vol 2 (No.4): 1-6. 